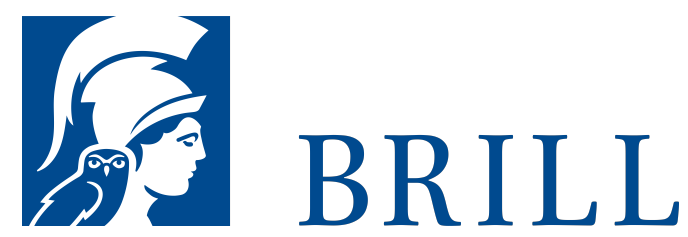

\title{
A Guide to the Zenon Archive
}

A. Lists and Surveys. B. Indexes and Maps

Author: P.W. Pestman

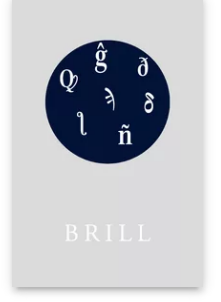

Pages: $x x, 466$ pp.; v, pp. 467-

7494

sketchmaps

Language:

English

Subjects:

General,

Classical

Studies,

Codicology,

Papyrology \&

Philology,

Ancient Near

East and Egypt

Publisher: Brill

Series:

Papyrologica

Lugduno-

Batava, Volume:

21

E-Book (PDF)

Released online: 28 Apr 2020

ISBN: 978-90-

04-42773-O

List price

USD Â $\$ 299.00$

Paperback

Publication date:

o1 Dec 1981

ISBN: 978-90-

o4-o6325-9 
For more information see brill.com

Order information: Order online at brill.com +44330 333 0049 | customerservices@brill.com Submission information: brill.com/authors

Titles published by Brill | Fink, Brill | mentis or Brill | Schöningh: +49(o)715413279216| brill@brocom.de 